\title{
AKIBAT HUKUM SEWA BELI SEPEDA MOTOR DENGAN ANGSURAN
}

\author{
Oleh : \\ I Gusti Lanang Agung Kesuma Jaya \\ Program studi Fakultas Hukum Universitas Mahendradatta \\ J1. Ken Arok No. 12, Peguyangan Denpasar Utara, Bali 80115. \\ (gungsume10@gmail.com)
}

\begin{abstract}
Abstrak,
Perjanjian sewa beli dengan angsuran lahir dari praktek kebiasaan masyarakat, yang sesuai dengan azas Hukum Perjanjian yang termuat didalam pasal 1338 KUH Perdata, sebagaimana diketahui BW menganut sistem bahwa perjanjian sewa beli itu hanya bersifat obligator saja, adapun hak milik baru berpindah dengan dilakukannya levering atau penyerahan. Adapun rumusan masalahnya adalah sebagai berikut Kapankah beralihnya hak milik dari penjual kepada pembeli dalam perjanjian sewa beli dengan angsuran ? dan Bagaimanakah akibat hukum apabila pembeli lalai membayar angsuran dalam perjanjian sewa beli dengan angsuran ?. Metode yang dipergunakan dengan melakukan penelitian lapangan terutama sewa beli motor dengan angsuran, dengan menggunakan data primer dan data skeunder. Beralihnya hak milik dari penjual lepada pembeli dalam perjanjian sewa beli dengan memberikan hak dan meletakkan kewajiban pada kedua belah pihak, yaitu memberikan kepada si pembeli hak untuk menuntut diserahkannya hak milik atas barang tersebut. Akibat hukum apabila pembeli lalai membayar angsuran dalam perjanjian sewa beli dengan angsuran yaitu apabila terjadi lalai dari perjanjian maka barang tersebut dapat di ambil atau di eksekusi karena debitur Debitur tidak memenuhi prestasinya. Adapun kesimpulannya adalah beralihnya hak milik dari penjual kepada pembeli dalam perjanjian sewa beli dengan angsuran adalah apabila pembeli telah melunasi angsuran sepeda motor kepada penjual atau didalam perjanjian sewa beli barang bergerak dengan angsuran hak milik atas barang tersebut baru beralih dari tangan penjual kepada pembeli apabila telah lunas. Akibat hukum apabila pembeli lalai dalam membayar.
\end{abstract}

Kata Kunci ; Akibat hukum ; Sewa beli ; Angsuran

\begin{abstract}
,
The lease purchase agreement with installments is born from the practice of the community, which is in accordance with the principle of Agreement Law contained in article 1338 of the Civil Code, as it is known BW adheres to the system that the lease agreement is only an obligator, while new ownership rights move by levering. The formulation of the problem is as follows When will the ownership of the seller switch to the buyer in the installment lease agreement? and what are the legal consequences if the buyer fails to pay
\end{abstract}


installments in the installment lease agreement? The method used by conducting field research is mainly motorbike rental purchases in installments, using primary data and secondary data. The transfer of ownership rights from the seller to the buyer in a lease agreement by giving rights and placing obligations on both parties, namely giving the buyer the right to demand the transfer of ownership rights to the item. Legal consequences if the buyer neglects to pay installments in an installment lease agreement, ie if there is a negligence of the agreement, the item can be taken or executed because the Debtor debtor does not fulfill his performance. The conclusion is the switching of ownership rights from the seller to the buyer in the installment lease agreement is if the buyer has paid off the motorcycle installments to the seller or in the lease agreement of movable goods with installments of the ownership of the goods has just switched from the seller's hand to the buyer when paid. Legal consequences if the buyer is negligent in paying.

Keywords ; Because of law ; Rent buy ; Installments

\section{PENDAHULUAN}

\subsection{Latar Belakang}

Dalam kehidupan sehari-hari manusia memenuhi kebutuhan hidupnya dengan berbagai macam cara, yang sudah tentunya tidak boleh bertentangan dengan norma kepatutan kesusilaan maupun hukum yang berlaku. Salah satu cara di dalam memenuhi kebutuhan hidup tersebut dengan mengadakan transaksi diantara manusia yang lainnya seperti tukar menukar, pinjam meminjam, sewa beli dan lain sebagainya.

\section{Berkaitan dengan hal tersebut diatas bahwa di dalam kehidupan masyarakat dewasa ini kita jumpai dalam}

6Wirjono Prodjodikoro, 1981, Hukum Perdata Tentang PersetujuanPersetujuan Tertentu, Cet. Ketujuh, praktek membeli barang secara mengangsur barang-barang tersebut bergerak tertentu seperti perabot rumah tangga maupun barang-barang lainnya misalnya TV, Sepeda Motor dan Mobil, yang merupakan salah satu kebutuhan masyarakat.

Wirjono Prodjodikoro menyebutkan bahwa : Hal ini sering terjadi dimasyarakat seorang membeli barang tidak mempunyai uang penuh untuk membayar harga pembelian sekaligus, dan ada keinginan supaya diizinkan membayar harga pembeli itu secara berangsur-angsur sedikit demi sedikit setiap bulan sebagian tertentu dari harga pembelian. ${ }^{6}$

Sumber Bandung (Selanjutnya disebut Wirjono Prodjodikoro I), hal. 65. 
Perjanjian sewa beli dengan angsuran lahir dari praktek kebiasaan masyarakat, yang sesuai dengan azas Hukum Perjanjian yang termuat didalam pasal 1338 KUH Perdata yang sering disebut sifat terbuka yang pada hakekatnya memberikan kebebasan dalam hal membuat perjanjian yang tidak boleh bertentangan dengan ketertiban umum dan kesusilaan. $^{7}$

Menurut RM. Suryodiningrat, bahwa : Penjual tidak menyerahkan hak milik atas barang yang dijualnya kepada pembeli dan pembeli membayar harganya secara angsuran setiap bulan atau setiap minggu, dan selama barang belum dibayar lunas, maka barang itu tetap milik penjual hal mana merupakan jaminan bagi penjual ${ }^{8}$

Pendapatnya R. Subekti, sejalan dengan pendapatnya M. Isa Arief, dalam bukunya Hukum Perdata dan Hukum Dagang, beliau menyebutkan bahwa harga barang dibayar dengan beberapa angsuran sedangkan barang-barang diserahkan pada

\footnotetext{
${ }^{7}$ Subekti, R, 1980, Pokok pokok Hukum Perdata, Intermasa Jakarta, hal 128.

${ }^{8}$ Subekti, R. 1982, Aneka Perjanjian, Alumni Bandung, hal. 66
}

waktu membayar angsuran yang pertama dengan demikian miliknya sudah berpindah lebih dahulu, sedangkan harganya belum habis dibayar. ${ }^{9}$

Bertitik tolak dari pandangan para sarjana diatas dimana disatu pihak menyebutkan bahwa didalam sewa beli angsuran tersebut belum memindahkan hak milik atas obyek sewa beli sebelum harga barang yang diangsur pembayarannya itu dilunasi, disini dapat dikatakan berpindahnya hak milik pada saat perjanjian sewa beli angsuran itu ditutup atau dilunasi. Namun dilain pihak dari pandangan kedua memberikan suatu pandangan bahwa berpindahnya hak milik dari barang atau obyek sewa beli angsuran adalah seketika setelah barangnya diserahkan oleh penjual kepada pembeli, tetapi harga barang tersebut dapat diangsur atau dicicil pembayarannya.

\subsection{Rumusan Masalah}

Dengan melihat kenyataan yang penulis kemukakan dalam latar belakang masalah, maka penulis mengangkat

${ }^{9}$ Isa Arief, 1979, Hukum Perdata, dan Hukum Dagang, Alumni Bandung, hal. 76-77 
masalah yang berkaitan dengan sewa beli barang bergerak dengan jalan angsuran. Adapun rumusan masalahnya adalah sebagai berikut:

1. Kapankah beralihnya hak milik dari penjual kepada pembeli dalam perjanjian sewa beli dengan angsuran ?

2. Bagaimanakah akibat hukum apabila pembeli lalai membayar angsuran dalam perjanjian sewa beli dengan angsuran?

\section{ISI MAKALAH}

\subsection{Metodelogi}

\subsubsection{Jenis Penelitian}

Penelitian yang penulis gunakan adalah penelitian emperis yaitu penelitian mengenai akibat hukum sewa beli sepeda motor dengan angsuran

\subsubsection{Jenis Pendekatan}

Pendekatan yang digunakan adalah pendekatan sosiologis yaitu pendekatan yang dilakukan terhadap fakta-fakta lapangan / masyarakat dan ditunjang dengan pendekatan yuridis yaitu pendekatan terhadap peraturan perundang-undangan/hukum perdata (BW).

\subsubsection{Sumber Data}

1. Sumber Data Primer

Dalam penulisan makalah ini data-data yang didapatkan bersumber dari hasil wawancara dengan informan yang memahami tentang permasalahan sewa beli sepeda motor dengan angsuran

2. Sumber Data sekunder

Dalam penulisan ini dengan menggunakan data sekunder dimana data yang digunakan adalah hasil penelitian lapangan dengan membandingkan peraturan perundangundangan.

\subsubsection{Teknik Pengumpulan Data}

Dalam teknik pengumpulan data penulis mengadakan wawancara kepada informan yang memahami permasalahan sewa beli sepeda motor dengan angsuran.

\subsubsection{Teknik Pengolahan dan Analisa}

Setelah data-data yang dibutuhkan terkumpul, maka data-data tersebut akan diolah dan dianalisa dengan menggunakan teknik pengolahan data secara diskriptif analisis kuantitatif yaitu, yaitu dengan memilih data yang berkualitas untuk dapat menjawab permasalahan yang diajukan, 
selanjutnya bahan hukum diolah dengan interpretasi. Dan untuk penyajiannya dilakukan secara deskriptif analisis kualitatif yaitu dengan menyusun secara sistimatis dari data yang ada kemudian dengan membutikan yang paling berkualitas dan setelah itu diolah sehingga diperoleh suatu kesimpulan yang ilmiah.

\subsection{Pembahasan}

\subsubsection{Beralihnya hak milik dari penjual kepada pembeli dalam perjanjian sewa beli dengan angsruan}

Seperti diketahui perjanjian jualbeli menurut sistem Kitab UndangUndang Hukum Perdata adalah bersifat obligator yakni jual-beli itu belum memindahkan hak milik, ia baru memberikan hak dan meletakkan kewajiban pada kedua belah pihak, yaitu memberikan kepada si pembeli hak untuk menuntut diserahkannya hak milik atas barang tersebut. Pemindahan hak milik baru akan terjadi apabila penyewa telah pelunasan terhadap kewajibannya sewa beli

10Soetojo Prawiro Namidjojo.R, Marthalana Pohan, 1984, Bab-bab
Disamping perjanjian sewa beli kita mengenal pula ada pemberian dan tukar menukar barang yang juga bertujuan untuk memindahkan hak milik, meskipun pada perjanjian jual-beli penjual hanya terikat secara obligator dan pembeli terikat secara pribadi, tetapi tujuan dari perjanjian jual-beli terletak pada pemindahan hak milik dari benda yang dijual dan oleh karena itu terjadilah perubahan dalam hubungan kebendaan, hal yang terakhir ini baru terjadi setelah direalisirnya perubahan itu. ${ }^{10}$

Kemudian didalam kewajiban menyerahkan suatu barang meliputi segala seguatu yang menjadi pelengkapnya serta dimaksudkan bagi pemakaiannya yang tetap beserta surat-surat bukti miliknya jika itu ada. Dengan demikian maka penyerahan sebidang tanah meliputi pula penyerahan sertifikatnya dan penyerahan kendaraan bermotor meliputi BPKBnya.

Dengan demikian yang ditentukan didalam memindahkan hak milik yang harus diserahkan kepada pembeli adalah suatu benda yang dapat dikuasai

Tentang Hukum Benda, Cet. Pertama, PT. Bina Ilmu, Surabaya, Hal. 39 
sepenuhnya tanpa dapat diganggu oleh siapapun sesuai dengan isi perjanjian sewa beli

Perjanjian sewa beli yang terjadi antara konsumen dengan dealer Kendaraan sepeda motor, apabila pihak pembeli dengan dealer telah disepakati oleh kedua belah pihak atas dasare perjanjian, pembeli diberikan hak pakai sebelum perjanjian sewa beli lunas. Apabila sewa beli lunas pemebeli diberikan surat-surat seperti BPKB oleh dealer kendaraan sepeda motor, dengan beralihnya hak milik dari penjual kepada pembeli, maka pembeli sebagai penguasaan penuh hak atas kendaraan yang dibeli.

Oleh karena pembeli belum menjadi pemilik mutlak dari barang tersebut, didalam jual-beli yang normal atau biasa dengan diserahkannya atau dilakukan penyerahan dan sekaligus pembayaran dari barang tersebut oleh pembeli ia sudah menjadi pemilik dan sudah mempunyai kekuasaan penuh, dan ia dapat mempergunakan barang itu bahkan menjualnya ataupun menghibahkan kepada pihak lain tanpa ada gangguan dari penjual.
Seperti telah disebutkan dalam membeli barang secara angsuran pembeli belum menjadi pemilik atas barang itu ia hanya mempunyai kekuasaan yang tidak penuh, oleh karenanya selama harga barang dibayar lunas oleh pembeli kepada penjual pihak pembeli tidak berhak untuk memindah tangankan, menjual atau menyewakan kepada pihak lain.

Suatu permasalahan akan timbulnya bagaimana halnya kalau sebelum lunas pembayarannya pembeli telah meninggal dunia. Untuk memecahkan permasalahan yang demikian ahli waris dari yang meninggal dunia tahu apa yang menjadi hak dan kewajibannya sebagai ahli waris.

\subsubsection{Akibat hukum apabila pembeli lalai membayar angsuran dalam perjanjian sewa beli dengan angsuran}

Akibat hukum yang timbul terhadap debitur yang mengalami wanprestasi dalam suatu perjanjian dimana debitur tidak memenuhi kewajibannya, secara nyata dapatlah dilihat bahwa akibatnya tidak dapatnya perjanjian dipenuhi atau dilaksanakan secara benar, maka seorang kreditur tidak mendapat pemenuhan hak- 
haknya yang semestinya didapatkan sesuai dengan adanya perjanjian tersebut. Akibatakibat yang diatur oleh hukum dalam suatu perjanjian adalah berupa sanksi-sanksi hukum penerapannya terdapat dalam KUH Perdata, sebagai peraturan formal yang mengatur perihal perjanjian-perjanjian beserta aspek yuridis lainnya. ${ }^{6}$

Dikenakannya sanksi hukum dalam suatu keadaan, wanprestasi pada suatu perjanjian sebagai ikatan disamping karena perjanjian merupakan suatu ikatan atau hubungan hukum adalah juga dikarenakan oleh dalam suatu perjanjian megandung asas obligatoir, yaitu meletakan hak dan kewajiban yang bertimbal balik. Konsekuensi dari atas obligatoir tersebut adalah jikalau salah satu pihak dalam perjanjian sebagaimana telah disepakatai, maka pihak dalam perjanjian sebagaimana telah disepakati, maka tidak dapat dibatalkan sepihak. Oleh Achmad Ichsan, asas obligator itu dikatakan sebagai segi-segi dalam perjanjian, sehingga menurut perjanjian memiliki 2 (dua) segi yaitu segi pasif berupa kewajiban dan segi aktif berupa hak. $^{7}$

Sedangkan segi pasifnya mempunyai 2 (dua) anasir lagi yakni kewajiban (schuld) dari debitur untuk melaksanakan suatu prestasi dan haftung atau tanggung jawab yuridis dari debitur atas kewajibannya. Dari dua anasir inilah kreditur dapat memaksa debitur untuk memenuhi kewajibannya

Menurut Prof. Purwahid Patrik, akibat hukum terhadap perjanjian karena wanprestasi, maka debitur harus :

1. Mengganti kerugian;

2. Benda yang dijadikan objek dari perikatan sejak saat tidak dipenuhinya kewajiban menjadi tanggungjawab dari debitur;

3. Jika perikatan itu timbul dari perjanjian yang timbal balik, kreditur dapat minta pembatalan (putusan) perjanjian. ${ }^{8}$
${ }^{6}$ RM. Suryodiningrat, 1997, Asas-asas Hukum Perikatan, Transito, Bandung, hal. 18.
${ }^{7}$ Achmad Uchsan,1977, Hukum Perdata, Pembimbing masa, Jakarta, hal.15
8 Purwahid Patrik,1997,. "Dasar-Dasar Hukum Perikatan", Bandar Maju, hal.11 
Hal tersebut juga dapat kita lihat dari penetapan pasal $1243 \mathrm{KUH}$ Perdata yang pada prinsipnya menentukan penggantian biaya, rugi dan bunga oleh pihak debitur baru dapat dilakukan, setelah debitur dinyatakan lalai karena tidak memenuhi isi perikatan. Para sarjana berpendapat agar melihat terlebih dahulu unsur-unsur yang harus diperhatikan sebelum seorang debitur dinyatakan dalam keadaan wanprestasi, karena wanprestasi (kelalaian) mempunyai akibat-akibat yang begitu penting, maka harus ditetapkan lebih dahulu apakah si berhutang melakukan wanprestasi atau lalai, dan kalau hal ini disangkal olehnya harus dibuktikan di muka hakim”.

Sedangkan dalam suatu perjanjian baik untuk menyerahkan atau berbuat sesuatu telah ditentukan dengan batas waktu, maka dengan lewatnya batas waktu pemenuhan kewajiban bagi debitur seketika itu pula debitur dapat dikatakan wanprestasi, karena dengan lewatnya tenggang waktu untuk memenuhi kewajiban seorang debitur tergolong lalai untuk memenuhi prestasinya. Adapun yang dimaksud dengan lalai dalam ketentuan pasal 1238 KUH Perdata ditentukan bahwa : "Si berhutang adalah lalai, bila ia dengan surat perintah atau dengan sebuah akte sejenis itu ia telah dinyatakan lalai, atau demi perikatan sendiri menetapkan bahwa si berhutang akan terus dianggap lalai dengan lewatnya waktu yang telah ditentukan".

Apabila seorang debitur sudah diperingatkan atau sudah dengan tegas ditagih janjinya, seperti yang diterangkan di atas, maka jika ia tetap tidak melaksanakan prestasinya, ia berada dalam keadaan lalai atau alpa sehigga dapat dikatakan sebagai keadaan wanprestasi dan terhadapnya ia dapat diperlakukan sanksi-sanksi yuridis sebagai akibat hukum daripadanya. Sanksi-sanksi hukum sebagaimana dimaksud di atas, dalam pasal 1243 KUH Perdata ditentukan bahwa "penggantian biaya, rugi dan bunga karena tidak dipenuhinya suatu perikatan, barulah mulai diwajibkan apabila si berhutang setelah dinyatakan lalai memenuhi perikatannya, tetap melalaikannya atau jika sesuatu yang harus diberikan atau dibuat tenggang waktu yang telah dilampaukan.”

Lain halnya dengan Abdulkadir Muhamad yang memberikan akibat 
hukum bagi debitur yang wanprestasi, dibagi menjadi 5 (lima) yaitu :

- Debitur diharuskan membayar ganti kerugian yang telah diberikan oleh kreditur;

- Dalam perjanjian timbal balik (bilateral) wanprestasi dari satu pihak, memberikan hak kepada pihak lainnya untuk membatalkan atau memutuskan perjanjian lewat hakim;

- Resiko beralih kepada debitur sejak saat terjadinya wanprestasi. Ketentuan ini hanya berlaku bagi perikatan untuk memberikan sesuatu;

- Membayar biaya perkara apabila diperkarakan dimuka hakim. Debitur yang terbukti melakukan wanprestasi tentu dikalahkan dalam perkara;

- Memenuhi perjanjian disertai dengan pembayaran ganti kerugian. ${ }^{9}$

Demikian halnya debitur harus bertanggung gugat tentang hal yang dapat

${ }^{9}$ Abdul Kadir Muhamad, 1982, Hukum Perikatan, Alumni Bandung, hal.89 dilakukan oleh kreditur menghadapi debitur yang wanprestasi adalah sebagai berikut :

1. Dapat menuntut pembatalan/pemutusan perjanjian;

2. Dapat menuntut pemenuhan perjanjian;

3. Dapat menuntut pengganti kerugian;

4. Dapat menuntut pembatalan dan pengganti kerugian;

5. Dapat menuntut pemenuhan dan pengganti kerugian.

Tidak dipenuhinya kewajibankewajiban yang telah ditetapkan didalam perikatan baik perikatan yang timbul karena perjanjian maupun yang timbul karena perjanjian maupun yang timbul karena undang-undang itu ada dua kemungkinan yaitu :

a. Karena kesalahan debitur, baik karena kesangajaan maupun karena kelalaian. 
b. Karena keadaan memaksa, jadi diluar kemampuan debitur, debitur tidak bersalah.

Keadaan-keadaan yang menentukan seorang dikatakan sengaja atau Ialai tidak memenuhi prestasi, antara lain ada 3 (tiga) keadaan :

a. Debitur tidak memenuhi prestasi sama sekali, artinya tidak memenuhi kewajiban yang telah disanggupinya untuk dipenuhi didalam suatu perjanjian atau tidak memenuhi kewajiban yang telah ditetapkan undangundang dalam perikatan yang timbul karena undangundang.

b. Debitur memenuhi prestasi tetapi tidak betul atau keliru, disini debitur melaksanakan atau memenuhi prestasi apa yang dijanjikan atau apa yang ditentukan oleh undang-undang, tetapi tidak sebagaimana mestinya menurut yang ditentukan dalam perjanjian.

c. Debitur memenuhi prestasi tetapi tidak tepat pada waktunya, disini debitur memenuhi prestasi tetapi terlambat.

Dengan demikian bagi debitur yang melakukan wanprestasi atau cidera janji akan membawa akibat hukum atau sanksi sebagai berikut : a. Debitur diharuskan membayar ganti kerugian yang telah diderita oleh kreditur.

b. Dalam perjanjian timbal-balik, wanprestasi dari satu pihak memberikan hak kepada pihak lainnya untuk membatalkan atau memutuskan perjanjian lewat hakim.

c. Resiko beralih kepada debitur sejak saat terjadinya wanprestasi.

d. Membayar biaya perkara apabila diperkarakan dimuka hakim.

e. Memenuhi perjanjian jika masih dapat dilakukan, atau pembatalan perjanjian disertai dengan pembayaran ganti kerugian.

Oleh undang-undang hal yang demikian itu ada demi hukum karena ada undang-undang yang mengaturnya, seperti sebagian besar mengenai peraturanperaturan tentang persetujuan-persetujuan dimana peraturan itu merupakan peraturan pelengkap (aanvullend recht), maka para pihak yang bersangkutan dapat menyimpang dengan mengadakan perjanjian yang bermaksud demikian.

Persoalan resiko adalah berpokok pangkal dari pada terjadinya suatu peristiwa diluar kesalahan salah satu 
pihak, peristiwa semacam itu didalam hukum perjanjian disebut sebagai keadaan memaksa atau overmacht, karenanya persoalan resiko itu merupakan awal dari persoalan tentang keadaan memaksa yaitu suatu keadaan yang menyebabkan bahwa suatu hak atau kewajiban dalam suatu perhubungan hukum tidak dilaksanakan.

Keadaan memaksa ini dapat bersifat absolut dan relatif. Keadaan memaksa dikatakan bersifat mutlak atau absolut bilamana keadaan memaksa tersebut mengakibatkan bahwa suatu hak atau kewajiban dalam perhubungan hukum sama sekali tidak dapat dilaksanakan oleh siapapun dan bagaimanapun juga.

Sedangkan keadaan memaksa dikatakan bersifat relatif apabila oleh keadaan itu pelaksanaan hak dan kewTajiban pada suatu perhubungan hukum tidak dapat dihilangkan sama sekali dan tidak dapat terjadi bagaimanapun juga, akan tetapi sukarnya dan dengan pengorbanan dari yang harus melaksanakan sedemikian rupa, sehingga

\footnotetext{
10 Wirjono Prodjodikoro, 1981, Asas-asas Hukum Perdata, Sumur
}

patutlah bahwa keharusan untuk melaksanakan hak dan kewajiban yang bersangkutan dianggap lenyap. ${ }^{10}$

\section{PENUTUP}

\subsection{Kesimpulan}

Setelah diuraikan secara pokokpokok mengenai perjanjian sewa beli secara angsuran barang bergerak, maka sebagai penutup dari uraian sampailah kepada kesimpulan dan saransaran sebagai berikut :

a. Beralihnya hak milik dari penjual kepada pembeli dalam perjanjian sewa beli dengan angsuran adalah apabila pembeli telah melunasi angsuran sepeda motor kepada penjual atau didalam perjanjian sewa beli barang bergerak dengan angsuran hak milik atas barang tersebut baru beralih dari tangan penjual kepada pembeli setelah dilunasi atau ditutupnya angsuran tersebut oleh pembeli, dan seketika itu pula penjual menyerahkan hak milik kepada pembeli sehingga pembeli dapat berbuat bebas atas barang tersebut.

Bandung, (Selanjutnya disebut Wirjono Prodjodikoro II), hal. 63. 
b. Akibat hukum apabila pembeli lalai dalam membayar angsuran sewa beli sepeda motor adalah : Pembeli diberikan surat peringatan sebanyak tiga kali, Apabila ternyata pembeli tidak memenuhi kewajibannya, maka penjual berhak untuk menarik kembali sepeda motor yang telah di terima oleh pembeli. Sedangkan uang angsuran yang telah dibayarkan oleh pembeli tidak dapat diminta kembali.

\subsection{Saran}

1. Oleh karena perjanjian sewa beli barang bergerak dengan angsuran sangat membantu perekonomian khususnya dibidang transaksi sewa beli, agar hal tersebut meyakinkan dan memberikan kepastian hukum kepada masing-masing pihak hendaknyalah didalam usaha pembentukan Hukum Perjanjian Nasional nantinya mendapat pengaturan yang tersendiri dan mampu memperkecil hal-hal yang negatif.

2. Mengingat perjanjian sewa beli dengan angsuran lahir dari praktek kebiasaan masyarakat hendaknya didalam pemenuhan rasa keadilan didalam menanggung resiko yang timbul diluar kesalahan para pihak, janganlah selalu dibebankan kepada pembeli yang belum menjadi pemilik barang tersebut, namun hendaknya diadakan pembagian menanggung resiko yang sama diantara para pihak.

\section{DAFTAR BACAAN}

Abdulkadir Muhammad, 1982, Hukum Perikatan, Alumni Bandung

Achmad Uchsan,1977, Hukum Perdata, Pembimbing masa, Jakarta

Isa Arief, 1979, Hukum Perdata, dan Hukum Dagang, Alumni Bandung

Purwahid Patrik,1997,. "Dasar-Dasar Hukum Perikatan”, Bandar Maju

Soetojo Prawiro Namidjojo.R, Marthalana Pohan, 1984, Bab-bab Tentang Hukum Benda, Cet. Pertama, PT. Bina Ilmu, Surabaya

Subekti, R, 1980, Pokok pokok Hukum Perdata, Intermasa Jakarta.

Subekti, R. 1982, Aneka Perjanjian, Alumni Bandung

Suryodiningrat, 1997, Asas-asas Hukum Perikatan, Transito, Bandung 
Wirjono Prodjodikoro, 1981, Asas-asas Hukum Perdata, Sumur Bandung, (Selanjutnya disebut Wirjono Prodjodikoro II)
Wirjono Prodjodikoro, 1981, Hukum Perdata Tentang PersetujuanPersetujuan Tertentu, Cet. Ketujuh, Sumber Bandung (Selanjutnya disebut Wirjono Prodjodikoro I) 